\title{
6 \\ Shakespeare and Paul in Illyria
}

In his lectures on Twelfth Night Emrys Jones insisted that 'the whole play drives toward the moment of the twins' reunion'. Indeed, reunion - better yet, resurrection - is (to use Molly Mahood's choice words) the principal 'governing idea' of the play. I will show that there is a link between reunion-resurrection, Candlemas, and William Shakespeare's own real-life drama that has been overlooked by his commentators and is key to appreciating his play.

Twelfth Night begins with Viola convinced that her brother, Sebastian, is dead; with practically her first breath she tells us ' $\mathrm{My}$ brother he is in Elysium' (1.1.4). So what we will be confronted with in 5.1 is not merely a family reunion but something of a resurrection. We must bear this in mind when we consider the personal significance for William Shakespeare of his play's performance on Candlemas.

Though we know Sebastian is alive, to Viola he is so convincingly dead that she has turned herself into his image. When she looks into her mirror she sees not herself but Sebastian.

I my brother know

Yet living in my glass; even such and so In favour was my brother, and he went Still in this fashion, colour, ornament, For him I imitate. (3.4.376-80, my emphasis)

This echoes Constance's (and Shakespeare's) lament for a lost son in King John: 'Grief fills the room up of my absent child ... Puts on his pretty looks ... Stuffs out his vacant garments' (3.4.93-8, my emphasis). Arthur had been kidnapped; Shakespeare's own son Hamnet has died. The grieving mother, sister, and playwright-father 
remember their boys' favour = pretty looks and fashion $=$ vacant garments. This is not just poetry; it's personal.

The date of Candlemas, 2 February, had a deeper significance for Shakespeare than has been recognized. His own fraternal twins, Judith and the deceased Hamnet, had been baptized in Holy Trinity Church at Stratford-upon-Avon on Candlemas, 2 February 1585. The date of Twelfth Night's performance at the Inns, 2 February 1602 - a date which can be expressed as 2.2.2 - was the seventeenth anniversary of the twins' baptism. By age eleven Hamnet was dead. Whether the cause of the boy's death was accident or illness - or did he perhaps drown in the River Avon? - is unknown. The parallels between the real and fictional fraternal twins are simply too pointed and poignant to ignore. Did Shakespeare recognize in his Judith flashes of his lost Hamnet? In Sebastian has Shakespeare, on a wish, resurrected his Hamnet and fashioned him as dashing, loyal, brave, handsome, witty - and then married him to a countess?

Curiously, from the dialogue between the twins at their reunion, neither seems prepared to take their good fortune at face value. Just as Viola believes her brother drowned, Sebastian believes Viola dead. There is wariness and scepticism in their words:

Seb. Do I stand there? I never had a brother;

Nor can there be that deity in my nature,

Of here and every where. I had a sister,

Whom the blind waves and surges have devour'd.

Of charity, what kin are you to me?

What countryman? what name? what parentage?

Vio. Of Messaline: Sebastian was my father;

Such a Sebastian was my brother too,

So went he suited to his watery tomb:

If spirits can assume both form and suit

You come to fright us.

Seb. A spirit I am indeed,

But am in that dimension grossly clad

Which from the womb I did participate.

Were you a woman, as the rest goes even,

I should my tears let fall upon your cheek,

And say 'Thrice-welcome, drowned Viola!' (5.1.222-37) 
Even now, Viola still doubts. She tries him with two more details.

Vio. My father had a mole upon his brow.

Seb. And so had mine.

Vio. And died that day when Viola from her birth had number'd thirteen years.

Seb. O, that record is lively in my soul!

He finished indeed his mortal act

That day that made my sister thirteen years. (5.1.238-44)

This is a reunion - and epiphany - very different from the sudden 'O, she's warm!' of Leontes in The Winter's Tale or Claudio's 'Another Hero!' at his bride's unmasking in Much Ado. In the climax of Twelfth Night, the parties to the mutual act of recognition approach each other with that precursor to and enemy of faith, doubt, before they embrace their resurrection and each other. It is their mutual doubt that lifts the moment above what might otherwise have passed as coincidence.

I suggest that on 2 February 1601/02 Shakespeare put before the auditors at the Inns of Court a play that was a mimetic response to his own misfortune, the tragedy of his own twins. And what he set on stage before the Queen on the true date of Epiphany was his own hope of heaven. The twins' reunion scene is steeped in pathos. To write it, Shakespeare must have paid a high price. He may have been a fervent Protestant or a recusant Catholic; we just don't know. But he couldn't have written this scene - this play - unless he was, at heart, a believer and a grieving father.

\section{Shakespeare's Paul}

To judging from his frequent citings, the Psalms and the Epistles of St Paul were among Shakespeare's favourite passages of Scripture. He wrote two plays set in locales Paul knew well: The Comedy of Errors in Ephesus and Twelfth Night in Illyria. Paul preached the Gospel in both places, and both plays were written for and/or performed before elite auditors at the Inns of Court and Whitehall. As Shakespeare developed each of these scripts he drew his plots from previously published plays and novels: Plautus' Menaechmi for Errors, Barnaby Riche's Apolonius and Silla for Twelfth Night. Then Shakespeare extensively engaged two of the Epistles 
of Paul: for The Comedy of Errors the Epistle to the Ephesians; for Twelfth Night the Epistles to the Corinthians. Shakespeare also relocated the action: Plautus' Epidamnum became Paul's Ephesus; Riche's Constantinople became Paul's Illyricum. By examining the secular and sacred sources of Twelfth Night in tandem, I propose to interrogate Shakespeare's method of composition and discover why he relocated the action in his source.

\section{Corinthians and Illyrians}

Shakespeare's principal source for Twelfth Night was the tale of Apolonius and Silla, which stood second in a collection by Barnaby Riche (ca. 1540-1617), Riche's Farewell to the Militarie Profession (1581). Some scholars are inclined to believe that Shakespeare also knew, in either its Italian original or French translation, Gl'ingannati ('The Deceived'), composed by the members of the Academy of the Intronati (The Bewildered) of Siena, performed in 1532 and published in 1537. I intend to briefly revisit each of these putative sources to consider elements Shakespeare may have drawn from them, and to illustrate material alterations he made as he merged the sources with Paul's letters to the Corinthians.

Gl'ingannati is a stagey but funny, bawdy play; by comparison Shakespeare's version is stuffy. The Italian comedy is set in contemporary Siena and, as it begins, young heroine Leila is already disguised in boy's clothing, has taken the name Fabio, and is employed as a page by her beloved Flamminio, who is lovesick for Isabella, who scorns him but lusts for Leila-Fabio. A similar love triangle appears in Twelfth Night with Viola-Cesario as the hypotenuse. The Italian play also includes wily servants, silly old men, and the timely return of Leila's twin brother, Fabrizio, kidnapped during the siege of Rome in 1527. When the latter is locked in Isabella's bedroom, she mistakes him for Leila-Fabio and beds him on sight, after which all conturbations sort themselves out (sort of). The idea to craft this story into a play purpose-written for performance on Twelfth Night may have occurred to Shakespeare while reading the prologue of Gl'ingannati. Its authors declare: 'The story is new and taken from nowhere but their own industrious pates whence also are taken your lots on Twelfth Night.' ${ }^{1}$ A reference to Twelfth Night also occurs in 1.2 of the Italian play. 
Riche's tale - itself based on Luigi Bandello's story Nicuola and Lattantio - is less sexual but far more sensational; the two iterations contrast the differing mores of (liberal) Italian and (repressed) English society. Riche provides only a half-hearted attempt at rape and a threatened but never-acted suicide. There is a shipwreck of which Silla is the sole survivor, an identical brother and sister, and the familiar tactic of a woman disguised as a man. In Riche's version, the missing brother, Silvio, is merely away from home. In Shakespeare's he becomes Sebastian, the fraternal twin believed drowned and dead. Both these alterations elevate the pathos of loss and thrill of reunion in Twelfth Night and demonstrate Shakespeare's skill at raising the stakes.

Shakespeare's most significant alteration to Riche's tale is the relocation of the action from the exotic venues of Constantinople and Cyprus to little-known Illyria. This raises an intriguing question: why was it necessary to remove the two stories to venues associated with Paul's letters? Couldn't the sententiae of Ephesians or Corinthians have been equally relevant in, say, Vienna or Venice? Of course they could. But Shakespeare relocated the stories to venues associated with his New Testament sources because in these places God enabled Paul to perform conspicuous miracles. Shakespeare moved the setting for Errors to Ephesus because it was there, $\mathrm{St}$ Luke tells us, that 'God wrought no small miracles by the handes of Paul' (Acts 19:11). In 2 Corinthians Paul declares, 'The signes of an Apostle were wrought among you with all patience, with signes, and wonders [miracles], and great workes' (12:12). Shakespeare's Olivia will declare the appearance or reunion of the twins before her 'Most wonderful' (5.1.235), that is, miraculous.

Shakespeare would make miracles happen in his Ephesus and Illyria as they did in Paul, and he wished his audience to be inclined to accept them as something more than coincidences. The Comedy of Errors includes what seems a minor miracle but is actually colossal; a clock that twice strikes the hour of one (4.2.52-62), which suggests that time went backwards to spare the life of Egeon until his family recognized him and each other. Such a miracle is recorded only once in the Old Testament; no commentator seems to have traced it to the prophets Hezekiah and Isaiah in 2 Kings 20 (see 'No small miracle: the twice-striking clock in The Comedy of Errors' in 'Longer notes' below). The miracle in Twelfth Night is visual rather than aural, and far more sensational: Shakespeare resurrects 
a 'dead' brother and reunites him with the twin sister whom he believed drowned and dead.

\section{The Elizabethans' Illyria}

What did 'Illyria' signify for Shakespeare's Elizabethan auditors? And what impression of Illyria did his auditors carry with them into the playhouse? For one thing, Elizabethans knew Paul brought the Gospel to Illyria. He says so in Romans: 'Through mighty signs and wonders [miracles], by the power of the Spirit of God; so that from Jerusalem, and round about unto Illyricum, I have fully preached the gospel of Christ' $(15: 19) .^{2}$ The region lies along the eastern Adriatic and now includes parts of the Balkan countries.

Between 229 and 169 BC, Romans crossed the Adriatic in successive waves of bandits, legions, merchants, and administrators who established the province of Illyris Romana, known as Barbara for its unruly tribes. By the time Paul arrived in Illyricum (ca. AD 54-8) Nero reigned as Emperor at Rome and there were thriving ports along its Dalmatian coast. Paul preached there while shuttling to and fro from Corinth. Figure 3 shows a portion of the calendar of daily readings for January in the Book of Common Prayer (1599).

Against the date 20 January (left arrow) is noted the Feast of Fabian (and Sebastian). A feast day began with its vigil, that is, at sunset of the prior day. The reading of 1 Corinthians began with evening prayer on the night of 19 January (right arrow), the vigil of the Feast of Fabian and Sebastian. So perhaps it's no coincidence that Shakespeare endowed two characters in Twelfth Night with the names of these minor saints. ${ }^{3}$ I will show that many of the themes Shakespeare explores in Twelfth Night were drawn directly from Paul's complaints about the behaviour of the Corinthians.

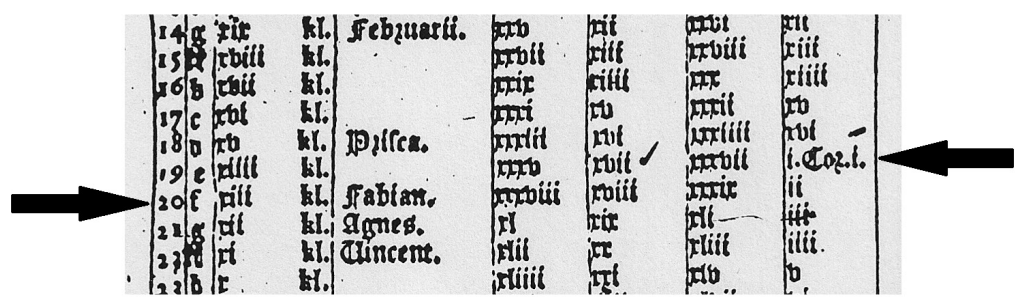

3 Book of Common Prayer calendar, January 


\section{Paul harangues the Corinthians}

Paul wrote two lengthy letters to the Corinthians and visited them three times. ${ }^{4} \mathrm{He}$ lavished attention because the idolatrous crew were having a hard time adapting to Paul's ascetic, egalitarian brand of Christianity. Let me enumerate some of their foibles which Paul castigated in 1 Corinthians; Shakespeare visited every one of these misbehaviours on his Illyrians.

Paul complains of divisions and factionalism between and within households: 'For it hath bene declared vnto me, my brethren of you by them that are of the house of Cloe, that there are contentions among you' (1 Corinthians 1:11). Certainly, there are contentions in the household of Olivia.

Paul deplores reports that stewards (like Malvolio) were in danger of becoming unfaithful: 'let a man so thinke of us, as of ... the disposers [King James Version: stewards] of the secrets of God. And as for the rest it is required of the disposers [stewards] that euery man be found faithful' (1 Corinthians 4:1-2).

Servants (Malvolio) were seized with ambition; Paul warned, 'Let euery man abide in the same vocation wherein he was called' (1 Corinthians 7:20). To those bridling at their low station he wrote, 'Art thou called [galled at] being a seruant? care not for it' (7:21). The marginal gloss in the Geneva Bible reads: 'Althogh God hathe called thee to serue in this life, yet thinke not thy condition vnworthie for a Christian ... For he that is called in the Lord, being a seruant, is the Lords freeman.'

Paul complains, 'It is heard certainely that there is fornication among you' (1 Corinthians 5:1). Paul orders Corinthians (Toby and Maria?) to 'Flee fornication: euery sinne that a man doeth, is without the bodie: but hee that committeth fornication, sinneth against his owne bodie' (6:28). Paul's sequence of ideas fornication $\rightarrow$ body apparently stuck in Shakespeare's mind: in 1.3 Toby urges Andrew to 'Accost [Maria] ... front her, boord her' (54-5); when she rebuffs him, the pair fall to talking about the quality of their bodies: hair, legs, throats, and dancing skills (92-100, 110-37).

Paul protests the Corinthians' bouts of raillery and drunkenness much like the revels in Olivia's household: 'When ye come together therefore into one place, this is not to eate the Lords Supper. For euery man when they should eate, taketh [eats] his owne supper 
afore, and one is hungry, and another is drunken.' (1 Corinthians 11:20-1). Indeed, for Shakespeare and Elizabethans Corinth was synonymous with dissipation and licentiousness; in 1 Henry IV the tavern-boys salute the layabout, carousing Hal as 'a Corinthian' (2.4.11).

Another problem: Corinthian men are becoming haughty. To use Paul's phrase, 'puffed up': 'Some are puffed vp as though I woulde not come vnto you.' (1 Corinthians 4:18). That's Malvolio's condition, as Fabian observes, 'see how imagination [ambition] blows him [up]' (2.5.40-1).

Paul also complained that some Corinthians were speaking in strange and undecipherable tongues, as will Andrew and Feste:

if I come vnto you speaking diuers tongues, what shall I profite you, except I speake to you, either by reuelation, or by knowledge, or by prophecying, or by doctrine? So likewise you, by the tongue, except yee vtter wordes that haue signification, howe shall it be vnderstand what is spoken? (1 Corinthians 14:1-9).

In 2.3, Andrew muddles, 'thou spok'st of Pigrogronitus, of the Vapians passing the equinoctial of Queubus', and Feste replies with a muddle of his own: 'I did impeticos thy gratillity: for Maluolios nose is no Whip-stocke. My Lady has a white hand, and the Mermidons are no bottle-ale houses' (2.3.21-27). ${ }^{5}$

A problem which Paul particularly deplored was that caritas was in decline among the Corinthians, and the collecting of alms had lapsed. Paul commanded them: 'Concerning the gathering [of alms] for the Saintes ... Euery first day of the weeke, let euery one of you put aside by himselfe, and lay vp as God hath prospered him, that then there [need] be no gatherings when I come' (1 Corinthians 16:1-3). Paul was a great beggar (as is Feste), who brought a substantial sum to support the Apostles and brethren in Jerusalem after fourteen years; I will show that Shakespeare remembers Paul's tale of this donation in Galatians 1:1 during Feste's exchange with Sebastian in 4.1.

Elizabethans who were regular readers of the Bible could not have failed to recognize a multitude of parallels between the problems Paul confronted in Corinth and those which Shakespeare contrived for his Illyria. Paul also reprimanded Christians for bringing lawsuits against each other in pagan courts: 'Dare any of you, hauing businesse against an other, be iudged vnder the vniust [pagans], and not 
vnder the Saintes? ... I speake it to your shame ... a brother goeth to law with a brother, and that vnder the infidels' (1 Corinthians 6:1-6). Doesn't this finally explain Shakespeare's sudden and otherwise inexplicable allusion to Malvolio's lawsuit against Viola's loyal Captain, 'The Captain that did bring me first on shore ... upon some action is now in durance at Malvolio's suit' (5.1.258-60)?

Most significant, Paul chastised the Corinthians for losing faith in the resurrection of the dead: 'Now if it be preached, that Christ is risen from the dead, how say some among you, that there is no resurrection of the dead?' (1 Corinthians 15:12-18). Isn't this the issue when Feste chastises Olivia for the protracted mourning of her brother?

Clo. Good madonna, why mournest thou?

$\mathrm{Ol}$. Good fool, for my brother's death.

Clo. I think his soul is in hell, madonna.

$\mathrm{Ol}$. I know his soul is in heaven, fool.

Clo. The more fool, madonna, to mourn for your Brother's soul being in heaven? $(1.5 .62-7)$

Twelfth Night is, first and foremost, a play about resurrection and reunion, the central, overarching and defining promise of Christianity: that faith in Christ can bring believers eternal life. Believing that Jesus was raised from the dead is the acid test for every Christian; the question for the faithful is not whether Jesus lived and died, but whether he died and lived. Faith in a resurrection and reunion with lost loved ones in another, better world is the preeminent governing idea of Shakespeare's play. It is present at Viola's first appearance: 'What should I do in Illyria? My brother he is in Elysium' (1.2.2-3). The wordplay on Illyria-Elysium immediately conjures a connection. Below I will have more to say about why I believe this was the opening scene of the play.

As Shakespeare did when he relocated The Comedy of Errors to Ephesus, he shifted the action of Twelfth Night from Constantinople to Illyria in order to bring into play an Epistle of St Paul. Paul's letter to the Corinthians not only inspired many themes of Shakespeare's comedy; it wraps the climactic reunion in Paul's promise of the miraculous resurrection of the dead. It's not difficult to see how, in the mind of a playwright mourning his only son, this scene was a dream come true. 


\section{Notes}

1 Geoffrey Bullough, Narrative and Dramatic Sources of Shakespeare, 7 vols (New York: Columbia University Press, 1975), II.287.

2 Modern commentators are divided as to whether Paul preached the Gospel in Illyria itself or merely 'as far as' Illyria, meaning he reached only the district's southern borders north of Greece.

3 Keir Elam, ed., Twelfth Night, The Arden Shakespeare, Series 3 (London: Bloomsbury, 2009), 23.

4 A third letter to the Corinthians is believed to have existed but is now lost.

5 The exact meaning of Feste's reposte still eludes Shakespeare's commentators. What seems plain is that Feste either pocketed the coin or slipped it to his leman = lady friend. 'Mermidons' is perhaps a glance at the Mermaid Inn, where Shakespeare and Jonson are said to have taken liquid refreshment of proper kegs, not bottled ale. 